\title{
the 2004 federal election: why labor failed
}

\section{By Paul D.Williams}

\section{Introduction}

1

he federal election of 9 October 2004 to elect Australia's forty-first parliament had its roots in unusual circumstances and yielded even more surprising results. On the heels of the Opposition's potentially destructive allegations of the Howard Government's deception over the socalled "children overboard" incident of late 2001, the Liberal-National Party (LNP) Coalition snared 46.7 per cent of the primary vote and 87 seats in the House of Representatives, or a net increase of five. ${ }^{1}$ The Coalition attained a 2.2 per cent swing to receive 52.8 per cent of the two-party-preferred (2PP) vote. The Liberal Party scored 40.5 per cent of the primary vote (an increase of 3.4 percentage points) to bring it to a near-majority in its own right of 74 seats (a net increase of six). The Nationals, with the loss of a single seat (Richmond, NSW), saw 12 members returned on 5.9 per cent of the primary vote: a tiny increase of 0.3 per cent.

For many, the greatest surprise came when the Australian Labor Party (ALP) managed to take just 60 seats (a net loss of five) with just 47.2 per cent of the $2 \mathrm{PP}$ vote. Moreover, Labor's primary vote declined by 0.2 percentage points to just 37.6 per cent, its lowest total since 1931, the year Lang Labor split from the ALP. Indeed, if the 1931 vote totals of the two Labor parties are added, then the ALP's 2004 result is, in fact, its worst since 1906, since before the birth of the modern party system. ${ }^{2}$ The unusualness of the 2004 result is further underscored by the Coalition's securing of a narrow majority, of 39 seats, in the Senate, the first won by any government since the 1977 election. Indeed, the Coalition returned four Senators (three Liberals and one National) in Queensland alone, and three in each of the remaining states. The Greens won two extra seats (Tasmania and Western Australia), while Family First (Victoria) secured its first federal representation. By contrast, the Australian Democrats lost all three recontesting Senators (Queensland, New South Wales,

Paul Williams is a lecturer in the Department of Politics and Public Policy at Griffith University in Brisbane.
Western Australia), while One Nation (Queensland) lost its sole representative.

The Coalition's victory was even more remarkable given the Government, seeking its fourth term, was pitted against a reinvigorated ALP Opposition led by a youthful - and seemingly popular - leader. But this poll was unusual for other reasons. First, the six week campaign was the longest since 1984 and, second, not since 1966 has a government secured a net increase of seats at two successive elections. These circumstances prompt an obvious question: why did the ALP perform so poorly at this point in the electoral cycle and in the wake of its potentially damaging allegations as to the Coalition's integrity?

This article argues that four sets of factors were at play: first, the pre-campaign period in which the Coalition laid critical economic preparations and the ALP made significant policy blunders; second, electors' positive perceptions of John Howard's leadership and less favourable perceptions of Mark Latham's; third, the campaign agenda itself in which the Coalition paraded its credentials on management of the economy and, more specifically, on interest rates; and, fourth, the ALP's "late-target" strategy of delayed policy release.

\section{Pre-election}

Prior to Mark Latham's elevation to the Labor leadership in December 2003, the ALP's public opinion standing under Simon Crean hovered, according to Newspoll, ${ }^{3}$ around 36 per cent of the primary vote, low enough to incur for Labor a proverbial "train wreck" result. Yet, three months after Latham's accession, the ALP attracted a landslide-inducing 46 per cent of the primary vote, or 55 per cent of the $2 \mathrm{PP}$ vote - its best result since early 2001. Latham's populist appeal, in which he pledged to wind back MPs' generous superannuation entitlements and to implement a "social compact" to strengthen health and education and to guard against "community breakdown", was undoubtedly a factor. ${ }^{4}$ Importantly, in a bid to distinguish himself from the Prime Minister, Latham also engaged in an attractive "triangulation" 5 of policy debate - a method adopted from the Clinton Presidency in the United States - in which Latham raised such left-field issues as children's literacy and obesity and the community's "crisis in masculinity". Latham's approach 
appeared to pay off: in early March, Newspoll found that Latham was preferred as Prime Minister by 42 per cent of voters and trailed Howard by just one point, a level never matched by Beazley. Moreover, 74 per cent of voters thought Latham to be "in touch" compared to only 56 per cent who similarly described Howard. Clearly, the Prime Minister was "wrong-footed" by a fresh and plain speaking Opposition leader who refused to combat the Government on its policy ground.

Yet, paradoxically, it is in this sanguine pre-campaign period that the roots of Labor's defeat can be found. Despite, or perhaps because of, Labor's triangulation strategy, Government MPs and political commentators soon condemned Latham for a lack of detailed economic policy. To counter a perception of vagueness, Latham vigorously engaged the Government not on economic policy but on national security - another area traditionally strong for the Coalition. Latham was undoubtedly emboldened by public opinion polls in February which indicated the electorate was evenly split in their opinion of the Iraqi conflict. More damagingly, a majority of voters believed the Prime Minister had misled the public - either knowingly or unknowingly - over the reasons for going to war. To this end, Latham declared in March - apparently without his colleagues' consultation - that a Labor Government would withdraw Australian troops from Iraq by Christmas 2004. The public opinion backlash was palpable: by May, Labor's primary support had fallen to 37 per cent. Latham's statement appeared to have three deleterious effects. First, it shunted conservative voters attracted to the innovative Latham back into the Coalition camp. Second, it shook the Labor caucus's tenuous confidence in Latham for advancing such a contentious position without adequate consultation. It must be remembered, of course, that Latham inherited a divided ALP by winning the leadership by the narrowest of margins. Third, the controversy of the ensuing debate truncated prematurely Latham's "honeymoon" with the public and, especially, the media. The overall result was that Latham's statement robbed the ALP of the momentum necessary to enter a campaign against a well-ensconced incumbent government. Labor later clawed back some public opinion ground, but the party never again reached its March peak.

\section{Leadership}

Voters' high regard for Howard's leadership, and lower regard for Latham's, was undoubtedly a critical factor in the Coalition's victory. Where, according to Newspoll, Latham's support for preferred prime minister in 2004 rarely rose above 35 per cent, Howard's was often over 50 per cent. At the campaign's close, Howard attracted 54 per cent to Latham's 31 per cent. Indeed, Howard capitalised upon voters' perceptions of leadership, and especially Latham's withdrawal statement, to contrast his "experience" with his counterpart's "inexperience". From long before the campaign's launch, Howard implored electors to decide their vote on the basis of which leader was better equipped to manage Australia's national security and, more acutely, the national economy. On the former, the government regained much support when - with the enthusiastic support of the American President George W. Bush who criticised Latham - Howard pledged he would not "cut and run" from Iraq. Once again, Howard emerged, as Bush had once labelled him, a "man of steel". On the latter, Howard and Costello in May delivered an exorbitantly generous Budget, with a $\$ 19$ billion family-welfare-tax package, including annual $\$ 600$ per child payments, as its centrepiece. ${ }^{6}$ The package was well received and allowed the Government to resume control of the political agenda. By late May, the Coalition could lay claim to 53 per cent of the $2 \mathrm{PP}$ vote. The seeds of the Coalition's re-election, then, were sown almost certainly in the 2004 Budget.

Despite these advances, Howard's leadership was again tested on three further occasions. The first, in early August, saw the Government concede to the Opposition two symbolic amendments to the Free Trade Agreement with the United States: one to ensure a minimum cultural content in Australian television programming; a second to keep low the price of pharmaceuticals. The ALP, at least momentarily, appeared to be the greater protector of Australia's national interest. On a second occasion, the Government was embarrassed by an open letter published by a group of 43 former senior diplomats and military personnel who alleged the Prime Minister had misled the Australian public over the reasons for participating in the war against Iraq. Several weeks later, a potentially more devastating development unfolded when a former 
Defence Department adviser, Mike Scrafton, claimed that he had explicitly informed the Prime Minister in late 2001 that no children had been thrown overboard during the Australian Navy's interception of SIEV IV, despite the claim's wide dissemination during the 2001 election campaign. These developments appeared to boost the ALP's support by mid August to 54 per cent of the $2 \mathrm{PP}$ vote and encouraged Latham to stake his party's electoral prospects on the issue of public "trust" in government. As discussed below, this proved an idealistic, if not misguided, strategy.

In terms of Latham's leadership, it is probable that swinging voters, despite admiring the Opposition Leader's personal qualities, refused to invest confidence in Latham as a credible alternative prime minister. This is supported by a post-election Galaxy public opinion poll which revealed that most voters did not perceive Latham as "statesmanlike". Instead, it is probable that Latham's plain speaking and loose delivery at press conferences - while initially refreshingly novel for voters - ultimately contrasted poorly with the concise style voters have come to expect from leaders. Other leadership problems included Latham's tendency to eschew policy and campaign advice and to run a "one man band". ${ }^{8}$ In short, it can be argued that the Latham leadership was an experiment that demonstrated early, short-term promise, but one that ultimately failed.

Labor's attempt to fan public discontent over Costello's succession to the Liberal Party leadership also appears to have failed. Clearly, the ALP overestimated the electorate's dissatisfaction with Costello. A March Newspoll, for example, found that 60 per cent of voters regarded the Treasurer as "capable", with 57 per cent describing him as "likeable". Moreover, 47 per cent determined Costello would make a "good" prime minister. Exit polls confirm these perceptions, with 68 per cent of Labor voters, and with 90 per cent of Coalition voters, being unconcerned with a Costello prime ministership. ${ }^{9}$ In short, the ALP spent a significant share of its campaign time and budget promoting the Liberal candidate for Higgins (Vic.).

\section{The Campaign}

The tone of the campaign itself - one pitched to an economic agenda set from day one by the Coalition - was undoubtedly a major influence on the result.
In terms of Latham's leadership, it is probable that swinging voters, despite admiring the Opposition Leader's personal qualities, refused to invest confidence in Latham as a credible alternative prime minister

While the impact of any campaign on any election result is contentious, the fact that, by the end of this campaign, 30 per cent of voters remained undecided (a level four percentage points higher than in 2001) suggests this longer campaign of six weeks was unusually critical. This statistic is especially germane: it is probable that the additional two weeks allowed the Coalition to extract maximum advantage by coaxing those latedeciding voters - fond of Latham yet wary of his style - backinto the Coalition camp.

It is even more critical to note that the Coalition, at no point, lost control of the campaign agenda. Announcing the election date at a press conference, Howard immediately confronted Labor's campaign declaration of a referendum on "trust" in government. Dangerously exposed on this issue following the Scrafton testimony, Howard neutralised Labor's strategy by defining "trust" in his own terms: rather than an issue of "truth-telling", Howard instead asked voters whom did they better trust to manage the national economy. In short, Howard cannily converted a potential negative into a resounding positive. To this end, the Coalition ran a series of television advertisements that, in arguing interest rates would always be higher under a Labor government, lampooned the records of Labor Prime Ministers from Whitlam to Keating. There is little doubt these advertisements struck voters' hip pockets. Exit polls in New South Wales, for example, revealed that 45 per cent of electors nominated interest rates as the reason for their vote choice. ${ }^{10}$ Two further points underscore the efficacy of the Coalition's campaign: record numbers of Australians now bear huge mortgages as a consequence of the most recent housing boom; and, according to recent research, and more damagingly for Labor, vast numbers of Australians fail to understand how interest rates are set. Ignoring the role of the Reserve Bank, many voters believed that a Labor government would deliberately raise interest rates - and therefore mortgage repayments - as a matter of policy course. ${ }^{11}$ 


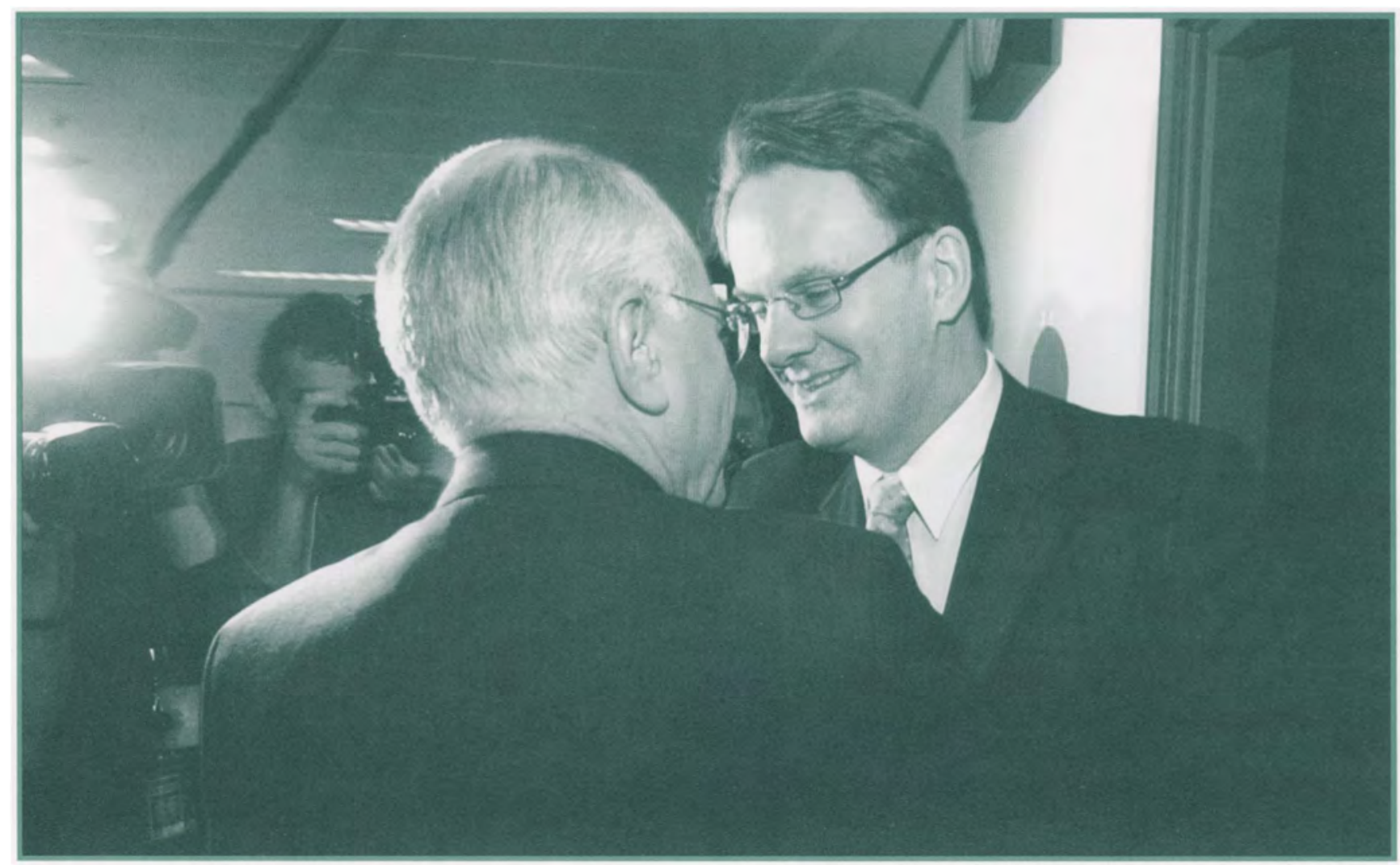

Photo: $A A^{P}$

The success of the Coalition's strategy was further reflected in public opinion polls: at no time during the campaign did the LNP's primary vote fall behind Labor's. At its best, in early September, the Coalition scored 46 per cent while, at its worst in late September, it scored 43 per cent. By contrast, the ALP peaked in mid September at just 41 per cent, and reached its nadir of 39 per cent in early October. Only in mid September, in terms of the 2PP vote did the ALP, on 52.5 per cent, momentarily overtake the Coalition. But any revival for Labor was ephemeral: the Coalition closed the campaign on 45 per cent of the primary vote, to Labor's 39 per cent.

\section{Policy}

A further significant factor in Labor's loss was the party's failure, on two levels, to find appropriate policy traction, even in areas the party traditionally dominates. On a general level, under its "late target" strategy in which core policies were released late in the campaign, the ALP failed to convincingly "sell" its policies as a comprehensive package. Designed to minimise the opportunity for Coalition scrutiny, the "late target" strategy instead encouraged Coalition criticism for an alleged lack of policy detail and, more critically, robbed swinging voters of much needed time to "digest" adequately Labor's offerings. A lack of credibility in the Labor program, and a loss of confidence in the party itself, was the inevitable result.

A second, more specific, reason was the nature and composition of the Labor program. While always expected to be at a disadvantage in economic debate, the ALP nonetheless failed to counter the Coalition's campaign against Labor's economic credentials. The ALP, for example, failed to remind electors of Labor's economic achievements during the Hawke and Keating Labor Governments. Moreover, the ALP could have launched its own pejorative campaign that highlighted Australia's ballooning foreign debt (an issue the Coalition used to great effect against the Keating Government in 1996), or exploited voters' concerns over the full sale of Telstra.

Yet Labor also failed to find acceptance among voters in areas of social policy. Tax relief and family benefits, for example, were issues ripe for Labor's picking, particularly given that 15 of the Coalition's 20 most marginal seats housed a majority of households earning less than $\$ 52000$ per annum and, therefore, had been neglected by the Coalition's May tax cuts. ${ }^{12}$ In terms of welfare, Labor's long-awaited family-tax policy both disappointed and perplexed voters. Following a gaffe by a Western Australian Labor MP, the party was forced to concede three out of ten families would be financially disadvantaged by its package. The party's schools policy scarcely fared better. In promising a redistribution of funding from the wealthiest private colleges to needier private and public schools, Labor appeared to over-estimate Australian voters' capacity to indulge in the "politics of envy". Rather than being championed as a defence of the underdog, Labor's policy instead 
was widely perceived as an attack on private schools generally, with Latham painted as an antediluvian "class warrior". Moreover, the party neglected the fact that a significant proportion of modest income families also educate their children at non-government schools. Labor's forest policy proved equally unpalatable among voters, particularly in regional Australia, and especially in Tasmania. In pledging to end logging in that state's old growth forests, the party alienated blue-collar workers in "sunset industries" already marginalised by globalisation and the march of economic reform. Indeed, some evidence suggests that up to one-third of trade union members voted for the Coalition. ${ }^{13}$ But it is the party's Medicare Gold policy - in which voters over 75 years of age were to enjoy free hospital care - that will undoubtedly be remembered as the most misdirected of Labor's campaign, and one in which Labor failed to find credibility on three fronts: first, in terms of its cost; second, it alienated those voters under 75 years content with the Coalition's private health insurance rebate; and third, and most critically, Labor failed to comprehend how solidly the over 75 years cohort is "rusted" onto the Coalition: to divert so much of its policy budget to such a hostile and immovable demographic is strategically curious.

\section{Conclusion - where to for Labor?}

This article has argued that four sets of factors contributed to Labor's unexpected reversal at the 2004 federal election, namely the critical pre-campaign period during which the Coalition delivered a well-received Budget, electors' contrasting perceptions of the leadership of John Howard and Mark Latham, the domination by interests rates of the campaign agenda, and the ALP's "late-target" strategy of policy release. From the above discussion, it can be concluded that these factors impacted negatively on the ALP in two broad ways: first, they robbed Labor of credibility as an alternative government among genuinely uncommitted voters and, second, they further disengaged traditional Labor voters from the party's already dwindling core support base.

Several other, more specific, conclusions can also be drawn. First, it appears that Australian voters rate sound economic management higher than "truth telling" in terms of public virtue. Second, in their rejection of Latham's novel leadership, it appears voters bear a preconceived idea of what image a prime minister should resemble. Third, the Greens' modest vote increase suggests the complexion of the Australian electorate is of a paler shade of green than many environmentalists had anticipated. Fourth, it is evident that the "late-target" strategy of delayed policy release failed to garner sufficient credibility among an increasingly sceptical electorate. And, last, the 2004 result confirms the long Australian pattern of elections confirming governments in office rather than changing them. Overall, it seems voters have once again come to regard the Liberal-National Coalition as the "natural" party of government.

A more pressing question, however, is exactly how the Coalition recaptured this mantle. It is, for example, likely that the trappings of incumbency allowed the Coalition, on two levels, to receive the electorate's "trust". On the first, the government (as opposed to the Coalition parties) waged an extensive public advertising campaign throughout 2004 on such issues as Medicare, domestic violence and Australian citizenship. This advantaged the Coalition by blurring in voters' minds the line between party and government. Second, the LNP's adept use of "spin doctors" allowed the Coalition to defuse potentially damaging political crises, including accusations of public deception. Overall, it appears each of these devices allowed the Government to engage in a form of public rhetoric that painted the Coalition as the protector of those policy areas once the province of Labor. Indeed, by campaign's end, the Coalition had managed to portray itself not only as the superior economic manager but, also, as the public defender of Medicare, school funding, family welfare and, in balancing conservation with jobs, the environment. For Labor, the future challenge is to blaze a trail back to electoral relevance, a task that will require not only a reconstruction of its policy program itself but, equally critically, a re-invention of its core "sales" strategy. This, of course, will inevitably mean a re-evaluation of Labor's relationship with key sectional groups, ranging from blue-collar unions to the business community. How effectively the party courts its disenchanted may well determine whether Labor returns to government in this decade or the next. $A Q$ 
The 2004 Federal Election:

\section{Why Labor failed}

1. All electoral data drawn from the Australian Electoral Commission (AEC) website. http://vtr.aec.gov.au/ AEC. 1999. Electoral Pocket Book. Australian Electora Commission: Canberra.

3. All public opinion data, unless otherwise stated, drawn from Newspoll website. http://www.newspoll.com.au/ cgi-bin/display_poll_data.pl

4. The Australian, 30 January 2004

P. Kelly. 2004. 'Captain Contradiction'. The Australian. 13 October.

6. The Australian, 12 May 2004

7. The Courier-Mail, 22 October 2004

The Australian, 26 October 2004

10. The Australian, 11 October 2004

10. The Australian, 11 October 2004

11. The Australian, 12 October 2004.
12. The Australian, 31 October 2004.

13. The Sydney Morning Herald, 16-17 October 2004

Religion in Australian Politics:

A Surfacing Debate

1. Annabel Crabb and Orietta Guerrera, 'PM Queries Values of State Schools', The Age, 20 January 2004.

. See discussion in Greg Barns, What's Wrong with the Liberal Party? (Cambridge: Cambridge University Press, 2003) 104-6.

3. Samantha Maiden and Peter Shadbolt, "Churches Savag Latharm', The Australian, 29 September 2004.

. Peter Costello, 'Address to National Day of Thanksgiving 29 May' (Commonwealth Treasurer, 2004 [Accessed 24 November 2004]); available from <www.treasurer.gov.au/ tsr/content/speeches/2004/007.asp

5. 'Editorial', The Age, 3 June 2004

Helen Irving, 'Australia's Foundations Were Definitely and Deliberately Not Christian,' (ON LINE opinion, $<$ www.onlineopinion,com.au> 9 ]une, 2004 [Accessed 24 November 2004]

7. 'Costello's Faith Call Hits Home', The Age, 17 July 2004 . Jason Koutsoukis and Misha Schubert, 'Latham UnChristian, Says Perth MP', The Age, 16 September 2004 Ibid.

10. George Pell, 'Christians, Even Bishops, Have a Right to Speak Out', The Sunday Telegraph, 24 October' 200

1. Thomas H Kean, The 9/1I Commission Report: Final Report of the National Commission on Terrorist Attack Upon the United States (New York: WW Norton \& Company [nc, 2004) 372

12. Helen Hardacre, "After Aum: Religion and Civil Society in Japan," in The State of Civil Society in Japan, ed. Frank I Schwartz and Susan J Pharr (Cambridge: Cambridge University Press, 2003), 148.

13. Ibid., 153 .

4. Tanya Nolan, Doomsday Cult Received Federal Funding (ABC Local Radio, AM transcript, 3 August: 2004).

15. The definition requires supernatural belief along with canons of conduct giving effect to that belief, (so long as these canons of conduct are legal), Church of the New Faith $v$ Commissioner of Pay-Roll Tax (Victoria) (1983) 154 CLR 120 Per Mason ACJ \& Brennan

16. See for example, MaxWallace, 'Is There a Separation of Church and State in Australia and NewZealand?' (New Zealand Association of Rationalists and Humanists Conference, Auckland, 16 October 2004)

17. Samuel P Huntington, The Clash of Civilizations and the Remaking of World Order, 2nd ed. (London: Simon \& Schuster UKLtd, 1997) 217-8.

18. Philip Ruddock, Ministerial Letter, 11 August 2004 Supplied to the author by CIFS (Cult Information \& Family Support Inc).

Just Not Good Enough

1. Robert W. Tucker, The Just War:A Study in Contemporar American Doctrine (Westport, Connecticut: Greenwood American Doctrine (Westport
Press, Publishers, 1978).p.1

2. For more detailed definition see Rudolf Peter, " "Gerechte Krieg," in Lexikon Der Politikwissenschaft: Theorien. Methoden, Begriffe, ed. Rainer-Olaf Schultze (München: Meck, 2002).p. 266

3. Laurie Calhoun, "Just War? Moral Soldiers?," Independen Review 4, no. 3 (2000).p327

4. Richard Falk, "Defining a Just War," The Nation (2001).; Jon Gorry, "'Just War' or Yust War? The Future(S) of a Tradition," Politics 20 , no. $3(2000)$.p. 178

5. Michael Schuck, "When the Shooting Stops: Missing Elements in Just War Theory," Christian Theory 111 , no. 30 (1994).

6. Lisa Sowle Cahill and Michael Baxter, "Is ThisWar Just?," US Catholic (2001). P.14

7. for this view see e.g.R.M Hare and C.B. Joynt, Ethics and International Affairs (London: Macmillan, 1982)., p.6; Joy Gordon, "Economic Sanctions, Just War Doctrine, and Gordon, "Economic Sanctions, Just War Doctrine, and the Fearful Spect

8. Sean Donahue quoted in Letters to the Editor., "Is This Really a 'Just War'?," The Nation 273 , no. 17 (2001).p. 6

9. GeorgeW. Bush 'State of the Union Address 2003' at The
White House Online http://www.whitehouse.gov/news/ releases $/ 2003 / 01 / \mathrm{print} / 20030128-19 . \mathrm{html}$ (accessed on 9 March 2003)

10. Jürgen Habermas, "Bestial ity and Humanity: A War on the Border between Legality and Morality," Constella. tions 6, no. 3 (1999).p.270

11. A.J. Coates, The Ethics of War (Manchester: Manchester University Press, 1997). p. 147

12. Laurie Calhoun. "The Injustice of "Just War"." Peace Review 12, no. 3(2000), p-454

13. International Commission on Intervention and State Sovereignty. The Responsibility to Protect. Ottowa: International Development Research Centre, 2001.p.49

4. Kofi Annan 'Annan to withdraw UN staff from Iraq' (17 March 2003) at $U N$ News Centre http: $/ /$ www.un.org/
apps/news/story.asp?NewsID $=6479 \& C r=i$ raq $\& C I 1=$ in ect (accessed on 18 March 2003)

5. Paul Baumann, "Limits of the Just War: Easier Said Than Done," Commonweal (1991). p.150

16. Michael Naumann, "Krieg in Den Trümmern Des Rechts," Die Zeit, no. 14 (2003).

17. Hans Magnus Enzensberger quoted in Assheuer, "Die Wiederentdeckung Der Moral Durch Alte Verächter," Die Zeit, no. 17 (1999).

Australian Perceptions of PKI Involvement in the Attempted Coup in Indonesia in 1965

1. Untung had previously been considered a national the first indonesian paratrooper to be dropped in West New Guinea as part of Sukarno's Mandala campaign to liberate' WNG and which was commanded by Suharto. It is also known that Suharto attended Untung's wedding in Yogyakarta. May asserts that the reason Suharto wasn't targeted by GESTAPU was a degree of loyalty felt by the former toward the latter. See Brian May The Indonesian Tragedy, London: Routledge and Keegan Paul, 1978, pp 97-98.

2. R.E. Elson Suharto: A Political Biography, Oakleigh, Vic Cambridge University Press, 2001, p 120. The Australtan Embassy in Jakarta noted in a Savingram dated 19 November 1965 that they knew little about Suharto. See Inward Savingram number 58 from Australian Embassy, Jakarta. Dated 19 November 1965, received 23 November 1965 . National Archives of Australia: A6364/4, IA1965/01S. 'Jakarta Savingrams Inwards Chronological numbers 2 to 66,6 fanuary 1965 to 7 January 1965'.

3. For example, Holtzappel explores the possibility that the attempted coup and its defeat by Suharto were part of a trap designed into which the PKI and its mass organisations fell. He asks, "Were the PKI and its mass organisations really and intentionally involved in the kidnapping and murder of the Generals as the Indonesian Army Information Service led both the press and the public to believe from the beginning? Or, had the communists fallen into a cleverly constructed trap as could be surmised from a number of trial documents?" See Coen Holtzappel 'The 30th September Movement: A Political Movernent of the Armed Forces or an Intelligence Operation?' Journal of Contemporar' Asia, vol. 9 , no. 2, 1979, p 220. See also W.F. Wertheim 'Whose Plot? New Light on the 1965 Events' Journal of Contemporary' Asia, vol. 9, no. 2, 1979. Crouch doubts the official version of the coup as an attempted communist seizure of powe See Harold Crouch 'Another Look at the Indonesian "Coup"', Indonesia, no. 15, 1973, pp 16 ff, Bernhard Dahm History of Indonesia in the Twentieth Century London: Pall Mall Press, 1971, p227, See Roger Paget'The Military in Indonesian Politics: The burden of Power' Pacific Affairs, vol. 40, nos. 3 and 4, Fall and Winter, 1967 and 1968, pp 294 ff and Benedict Anderson and Ruth McVey
A Preliminary Analysis of the October I, 1965 Coup in Indonesia Ithaca: Modern Indonesia Project Cornell University, 1971, pp 89-95.

4. For a more thorough treatment of events surrounding the attempted coup see Harold Crouch The srmyand Politios in Indonesia, Ithaca: Cornell University Press, 1978. See in indonesia, thaca: Comell University Press, 1978. See also Benedict RAnderson and Ruth McVey A Preliminary Analysis of the October I, 1965 Coup in Indonesia, Ith Modern Indonesia Project, Southeast Asia Program,

5. I.D. Legge Sukarno: A Political Biography, North Sydney: Allen and Unwin, 1990, p 391.

6. Record of Conversation with I. Rookmaarker, Director of East Asian Affairs at Netherlands Foreign ministry, 20 October 1965 . Report prepared by $\mathrm{J}$. McCredie and E. Burtmanis. NAA: A $1838 / 280,3034 / 2 / 1 / 8$ Part 4 . 'Indonesia - Political - Coup d'Etat of October 1965'.

7. Submission prepared by Sir Andrew Gilchrist, no date NAA: A1838/280, 3034/2/1/8 Part 4. 'Indonesia - Political -Coup d'Etat of October 1965'

8. Inward Savingtam number 66 from Australian Embassy, Moscow. Dated 2 November 1965, received 3 November 1965. NAA: A1838/280, 3034/2/1/8 Part 5. 'Indonesia -Coup d'Etat of October 1965'.

9. Record of Conversation with Mr L. Gardziuk, Firs Secretary, Polish Embassy, Jakarta, with Harvey Barnett. 20 October 1965. NAA: A1838/280, 3034/2/1/8 Part

10. For a biographical treatment, see Who's Who in Australia 23rd Edition, Melbourne: Herald and Weekly Times, 1980 p751.

'Contacts with Colleagues on the GESTAPU', by Keith Shann. Memorandum number 1278, 9 October 1965. NAA: A1838/280, 3034/2/1/8 Part 2. 'Indonesia-Political - Coup d'Etat of October 1965:

2. United States Foreign Service Telegram. No Date. NAA: 1838/280, 3034/2/1/8 Part 1.'Indonesia - Political -Coup d'Etat of October 1965'

13. Inward Cablegram number 3445 from Keith Waller, Australian Embassy, Washington D.C. Dated 4 October 1965, eerved 5 October 1365 . NAA. A1838/280,3034/2/1/8 1965:

14. For a biographical treatment, see Who's Who in Australia 22nd Edition Melbourne: Herald andWeekly Times, 1977, p 904.

15. Record of Conversation with DoyleV. Martin, Counselor, U.S. Embassy, Canberra, 5 October 1965. Recorded by Alan Renouf. NAA:A1838/280, 3034/2/1 Part 47.

Genera.'.

16. Inward Cablegram number 3442 from Australian received 5 October 1965. NAA: A1838/280, 3034/2/1/8 Part l. 'Indonesia-Political-Coup d'Etat of October 1965:

17. Cablegram from Shann to External Affairs, Canberra o. 1201. Dated and Received 12 October 1965. NAA: (1838/280,3034/2/1/8 Part 1.'

18. Weekly Political Savingam from Shann to External Affairs, Canberra. Sent: 11 October 1965. NAA: A1838/ 280, 3034/2/1/8 Part 1. 'Indonesia - Political-Coup d'Etat of October $1965^{\prime}$.

19. Departmental Briefing Paper entitled 'Indonesia: PAsible Future Developments'. No date, no author. - Coup d'Etat of October 1965'.

20. Compilation of Savingram excerpts relating to the attempted coup, compiled by G. Miller, 1 December 1965 NAA: Al838/280, 3034/2/1/8 Part 8. 'Indonesia-Political - Coup d'Etat of October 1965

21. Ibid.

23. Ibid. Shann here was citing unconfirmed French information.

24. Ibid.

26. 'Some Notes on the Jakarta Situation', 2 October 196 note by Shann. NAA:A1838/280, 3034/2/1/8 Part 2 . 'Indonesia - Political - Coup d'Etat of October 1965 '

27. lbid.

28. Ibid.

29. Ibid.

30. Ibid.

1. Ibid.

Outward Cablegram number 116 to All Posts. Sen 9 October 1966. NAA: A1838/280, 3034/2/1/8 Part 1 . 'Indonesia - Political - Coup d'Etat of October 1965'

33. Ibid.

34. Crouch The Army and Politics in Indonesia, $\mathrm{p} 51$.

35. In a pre-coup 1965 briefing paper for that year's ANZUS Ministerial Talks, it was noted that 'The balance of power within Indonesia is moving in favour of the PKI'. NAM A1838/280, 3034/2/1 Part 46. Indonesia - Political - General.

36. Departmental Memo, 10 November 1965. No author NAA: A1838/280,3034/2/1/8 Part 5. 'Indonesia - Political - Coup d'Etat of October $1965^{\circ}$

37. Memo for Mr Border, no author, 10 November 1965 NAA:A1838/280,3034/2/1/8 Part 5. 'Indonesia - Political - Coup d'Etat of October 1965'

38. Ibid.

9. Paper by G. Miller, I December 1965. NAA:Al838/280, 3034/2/1/8 Part 5. 'Indonesia - Political - Coup d'Etato October $1965^{\circ}$

40. Departmental Briefing Paper entitled 'The PKI Holds Its Fire', 6 December 1965, no author. NAA: A1838/280 3034/2/2/2 Part 11. 'Indonesia - Internal-Communism'

41. Paper by M.A. Jaspan entitled, 'Indonesia: Counter Revolution and Rebellion-An interpretive Analysis', no date. NAA: A1838/280, 3034/2/1/8 Part 7. 'Indonesia - Political - Coup d'Etat of October 1965.

42. Record of Conversation with Dr Subandrio, 15 Decembe 1965. Recorded by Peter Hastings. NAA: A1838/280, 3034/2/1 Part 8. 'Indonesia - Political-General'.

43. Excerpt from Joint Intelligence Paper, "Indonesia: Responsibility for the Attempted Coup', November 1965. NAA:AI838/280, 3034/2/1/8 Part 7. 'Indonesia - Political - Coup d'Etat of October 1965 .

44. Elson Suharto:A Political Biography, 120.

45. Draft Parliamentary statement on Indonesia, no date, no author. NAA: A1838/280, 3034/2/1/8 Part 1. 'Indonesia - Political-Coup d'Etat of October 1965'.

46. CPD HRVol. 49, pp 1913-14.

47. CPD HR Vol. $55, \mathrm{p} 2140$. For a more thorough treatment of Parliamentary debate on Australia's relations with Indonesia in the period under examination, see Stephe Harris Australian Diplomacy and Public Attitudes Towards Indonesia 1965-80, University of Tasmania PhD Thesis, 1988, pp 180-211 